\title{
Anmeldelser
}

Tips om medisinsk litteratur, andre bøker, filmer og elektroniske medier som bør anmeldes, sendes tidsskriftet@legeforeningen.no

\section{Referanseverk om søvnforstyrrelser}

Kushida CA, red.

Handbook of sleep disorders

2. utg. 694 s, tab, ill. London: Informa

Healthcare, 2008. Pris GBP 175

ISBN 978-0-8493-7319-0

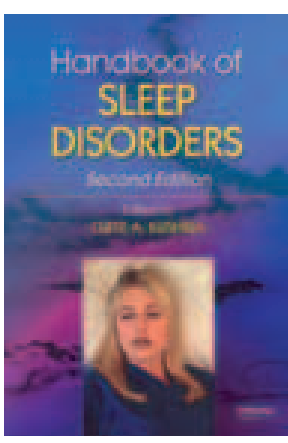

Dette er annen utgave av Handbook of sleep disorders, redigert av Clete A. Kushida, et klassisk referanseverk om søvnmedisin. Innholdet er organisert i samsvar med det nye diagnosesystemet for søvnforstyrrelser fra the American Academy of Sleep Medicine, som kom i 2005. Søvnforstyrrelsene deles nå inn i seks kategorier: insomnier, døgnrytmeforstyrrelser, søvnrelaterte bevegelsesforstyrrelser, søvnrelaterte respirasjonsforstyrrelser, hypersomnier og parasomnier. I denne utgaven er hver av disse kategoriene beskrevet nærmere i underkapitler, og totalt er det 52 slike underkapitler over nesten 700 sider. Her diskuteres epidemiologi, diagnostisk metodologi, komorbide lidelser, kliniske kjennetegn og behandlingsmetoder. Hvert kapittel inneholder referanselister for videre lesning, og det er en god stikkordliste. Målgruppen er alle helsearbeidere som behandler søvnforstyrrelser.

Søvnmedisin er ingen gammel vitenskap. Her er dette illustrert ved at en av bidragsyterne, den gamle Stanford-professoren W.C. Dement, er mannen som oppdaget og beskrev REM-søvnen (rapid eye movement) i midten av 1950-årene. Han startet også verdens først søvnklinikk og er, som man forstår, fremdeles meget aktiv. I tillegg til denne grand old man er det 88 andre bidragsytere - de aller fleste kjente størrelser innen søvnmedisinen.

Det faglige innholdet er meget solid. Alle de kjente forhold rundt søvnforstyrrelser er beskrevet. I det ligger det at svært mye ikke er beskrevet - ganske enkelt fordi det innen søvnmedisinen ennå er mange hvite flekker på kartet. Om Handbook of sleep disorders er en god lærebok, er et annet spørsmål.

I og for seg er den det, ettersom teksten er relativt lettlest, men det er skuffende at det knapt er en figur eller et bilde, noe som innimellom gjør den tung og tørr. Videre er layouten overraskende enkel, nesten billig hvilket står i stor kontrast til både det flotte faglige innholdet og den stive prisen. Er man på jakt etter et referanseverk om søvn, så er dette likevel et trygt valg.

\section{Arne Fetveit}

Seksjon for allmennmedisin

Institutt for allmenn- og samfunnsmedisin Universitetet i Oslo

\section{Ikke den beste søvnmedisinen}

Pandi-Perumal SR, Verster JC,

Monti JM et al, red.

\section{Sleep disorders}

Diagnosis and therapeutics. 724 s. tab, ill.

London: Informa Healthcare, 2008.

Pris GBP 199

ISBN 978-0-415-43818-6

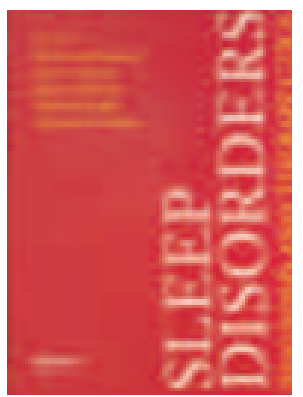

Hovedtemaer er søvnens farmakologi og farmakologisk behandling av søvnforstyrrelser. Dette skal være en introduksjonsbok for klinikere og forskere som er nye i feltet søvnfarmakologi, samtidig som den skal gi oppdaterte anbefalinger til erfarne søvnklinikere om metoder og behandlingsvalg ved søvnforstyrrelser.

Forfatterne er et utvalg forskere innenfor eksperimentell og klinisk søvnpsykofarmakologi. I tråd med dette er det 23 kapitler om farmakologisk behandling av søvnlidelser, fem kapitler om bivirkninger og abstinenssymptomer knyttet til farmakologisk behandling, seks kapitler om søvnens nevrobiologi og ytterligere fem kapitler om hvordan psykofarmaka for psykiatriske lidelser samt rusmidler påvirker søvnen. Kun ett kapittel omhandler psykologiske og atferdsorienterte tilnærminger. Denne vektleggingen av det farmakologiske er i tråd med den angitte intensjon om å belyse det farmakologiske aspektet ved søvn. Likevel, i kapitlet om psykologisk behandling og også i enkelte andre kapitler påpekes det at det er de psykologiske og atferdsmessige intervensjonene som ut fra studier om behandlingseffekt av den mest hyppige søvnlidelsen, insomni, har best effekt. Insomni opptrer hos omtrent halvparten av dem med søvnlidelser.

Derfor gir ikke Sleep disorders et balansert bilde i tråd med eksisterende viten om behandlingseffekter. Dette er for så vidt i tråd med at redaktørene er knyttet til institutter og private selskaper for psykofarmakologisk forskning og behandling, men det begrenser utgivelsens verdi for klinikere som måtte ønske seg en balansert fremstilling av behandlingsmulighetene. Bekymringen understrekes ved den sterke vektleggingen av farmakologisk behandling uansett type søvnlidelse. Det virker også noe for sterkt å karakterisere en søvnløs natt grunnet opprivende hendelser («forbigående insomni») som en medisinsk lidelse som bør behandles medikamentelt - særlig ettersom det samtidig nevnes at medikamenter har en rekke bivirkninger.

I forordet påpeker redaktørene at bivirkninger knyttet til benzodiazepiner er en viktig årsak til at mange klinikere har valgt ikke-farmakologiske behandlinger for særlig insomni. Dette presenteres som en rasjonale for den sterke vektleggingen av nye, mulige farmakologiske intervensjoner - herav flere som fremdeles er på eksperimentstadiet. Det er grunn til å ha en sunn porsjon skepsis til en slik vinkling, gitt at mye taler for at ikke-farmakologisk behandling ofte er den beste intervensjonen ved insomni, med mer varig effekt og uten bivirkninger sammenliknet med farmakologisk behandling.

De 55 hovedkapitlene er ikke sortert under hovedtemaer eller kategorier, noe som gjør det vanskelig å få oversikt. Rekkefølgen virker tilfeldig, og stadig er det gjentakelser.

Dette noe forvirrende oppsettet kan illustreres med to kapitler som presenterer drømmer, ett om drømmens «fysiologi, farmakologi og psykologi» og ett om hvordan medikamenter påvirker drømmer. Relevansen av disse kapitlene for en forståelse av søvnlidelser er ikke tydelig, og det blir direkte forvirrende når ett av kapitlene om drømmer omhandler hvordan medikamenter påvirker innsovningsprosessen som sådan. Denne uklarheten forsterkes av at presentasjonen av drømmen er svært anakronistisk og lite oppdatert, dels direkte feilaktig, som når det sies at søvnen innledes og opprettholdes ved at nevroner som 
produserer serotonin blir aktive. Eller ved presentasjon av teorier om drøm («Winsons teori») som undertegnede, som har arbeidet i dette feltet i ti år, aldri har hørt om tidligere. Dette svekker troverdigheten. Jeg kunne tenke meg en betydelig bedre lærebok om søvnlidelser enn dette.

Roar Fosse

Psykisk helse

Sykehuset Asker og Bærum

\section{Hvilken terapi?}

Arnet E.

Terapi

Hva passer for meg? 212 s. Oslo: Gyldendal

Akademisk, 2009. Pris NOK 295

ISBN 978-82-05-38898-7

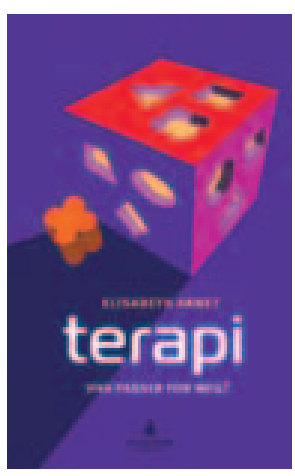

Forfatter Elisabeth

Arnet henvender

seg til alle som

ønsker å gå i terapi

og vil vite mer om

hva som karakteri-

serer ulike terapi-

former. I tillegg får

vi en kort innføring

i det teoretiske

grunnlaget for hver

av terapiformene

som presenteres.

Forfatteren starter med å alminneliggjøre behovet for å gå i terapi, for så å gi en generell innføring i hva det innebærer. Ni ulike terapiformer blir presentert, de fleste i eget kapittel. På slutten av hvert kapittel gir forfatteren eksempel på hvordan samtalen vil være innenfor den terapi som presenteres. Selvhjelpsgrupper blir også kortfattet omtalt. Til slutt gir forfatteren stemme til mennesker som har vært i terapi og som forteller hvordan de opplevde det å gå $\mathrm{i}$ terapi og hvilket utbytte de har hatt. Til slutt i boken er det oversikt over en del nettressurser, med adresser til ulike terapiinstitutter og foreninger.

De ulike terapiformene presenteres ryddig og kortfattet, uten bruk av mange vanskelige ord og faglig sjargong. Forfatteren starter med å omtale hva terapi hos psykolog er, for så å beskrive psykoanalyse. Men jeg savner en generell innføring i hva psykoterapi er. Det er også flere alminnelige terapiformer og -retninger som er i bruk innen spesialisthelsetjenesten som ikke omtales, som f.eks. gruppeterapi og mentalisering. Det brukes derimot mye plass på marginale terapiformer som «innerlife»-terapi og rosenterapi. Den største mangelen er at forfatteren ikke går mer i dybden og gir plass til hvordan en som går i terapi skal kunne vurdere om den hjelper eller ikke. Hun sier flere ganger at kjemien må stemme - gjør den ikke det, kan man skifte terapeut. Men er det et riktig faglig råd - og realistisk å få til? Psykiatere som terapeuter blir nesten ikke omtalt.

Er dette en bok jeg kan anbefale? Deler av den er lettfattelig og informativ, og det er helt sikkert et behov for denne type opplysning. I tittelen angis det at boken skal gi generell informasjon om hva terapi er, og det gjør den dessverre bare delvis. Boken preges i for stor grad av forfatterens syn på hva terapi er. Boken henvender seg også i for stor grad til mennesker med mindre alvorlige psykiske plager og berører ikke hva terapi er for mennesker med langvarige alvorlige psykiske plager, som alvorlig depresjon og psykoser. Konklusjonen er at boken har nyttig informasjon, men er for snever i omtale av hva terapi er.

\section{Ann Færden}

Avdeling for forskning og undervisning

Oslo universitetssykehus, Ullevål

\section{En samtale om kropp og smerte?}

Pihl M.

Det andre muskellaget

86 s, ill. Oslo: Kolofon forlag, 2009. Pris NOK 235 ISBN 978-82-300-0509-5

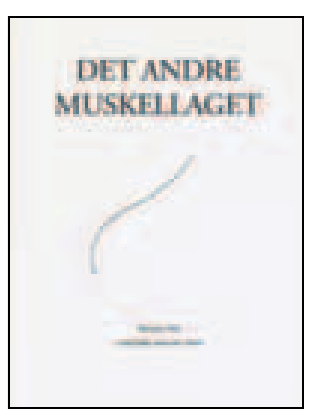

Forfatteren Merete Pihl er psykomotorisk fysioterapeut med mange års erfaring som terapeut og lærer. Hun har valgt å skrive om denne erfaringen med sin egen kropp og sine egne tap som utgangspunkt. Refleksjonene over bevegelser og smerter, som hun lar leseren tar del i, er en førstepersons fortelling til en annen person, en anonym venn, som responderer. Leseren blir slik en tredjeperson - om han eller hun vil - som blir betrodd intim viten om forfatteren, dog på en måte som virker kryptert eller kodet. Slik forblir personen som snakker skjult som bak et slør, en som angir å ville vise seg, men likevel ikke gjør det.

Denne forunderlige formen for utydelighet blir understreket av at vennens responser ikke står i noe åpenbart logisk meningsforhold til forfatterens forutgående beskrivelser eller betroelser. Og siden leseren må anta at vennen svarer eller kommenterer ut fra en stor fortrolighet med forfatteren, holder de to samtalende personene leseren $\mathrm{i}$ en viss forstand utenfor.

Kan det tenkes at forfatteren både vil og ikke vil vise seg? Og hva vil hun oppnå ved ikke å oppgi sin ambivalens? Vil hun skape forvirring? Vil hun vekke skjerpet oppmerksomhet? Hun omtaler tidlig en liten jente i seg selv, den voksne kvinnen, en jente som ikke ble den hun var ment å være. Leseren ser kvinnen som invalidiseres av smerte og utmattelse, som rammes av brystkreft og cellegift. Og i et lite glimt ser leseren en liten jente som ble stående igjen da familien reiste fra henne i en grønn bil. Hun ble - for veldig lenge siden - etterlatt på et rekonvalesenthjem for barn «for å få i seg nok proteiner»».

Var det da pusten stoppet og musklene utenpå og inne i kroppen mistet sitt selvfølgelige, trygge og vitalitetsbevarende samvirke? Er det dette bruddet forfatteren prøver å hele i sine øvelser på gulvet og med sin egen terapeut i sine forsøk på å samstemme musklene igjen? Er det betydningen av et biografisk brudd, ment for å bevare hennes helse, som fortelleren vil formidle til sine kolleger i helsefagene? Vil hun, selv en profesjonell hjelper, bruke seg selv for å gjøre andre hjelpere oppmerksomme på hvor vanskelig det er for fortvilte mennesker å «løfte på sløret» som skjuler kildene til deres fortvilelse, smerte og angst?

\section{Anna Luise Kirkengen}

Senter for helsefremmende arbeid Akershus universitetssykehus

\section{En ullen sak}

\section{Porthun J.}

Osteopati

For spedbarn, barn og voksne. $68 \mathrm{~s}$, ill.

Bøverbu: Ondefo forlag, 2008. Pris NOK 129 ISBN 978-82-8190045-5

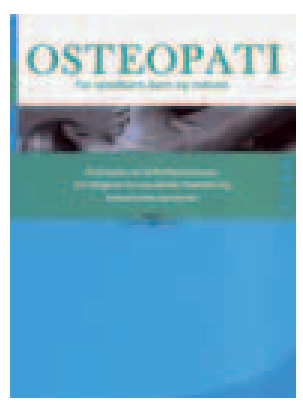

Forfatteren henvender seg i første omgang til pasienter, foreldre og potensielle pasienter og forsøker å gi en oversikt over osteopati som behandlingsform. Osteopati fremheves som et helhet-

lig, svært omfangsrikt konsept innenfor det helsefaglige området. De enkelte sykdommer eller plager er ikke hovedsaken, det er individet i sin helhet som står i sentrum. Osteopati retter seg mot hele mennesket. En osteopatisk terapeut søker etter årsaken til plager og sykdommer.

Undersøkelse og behandling foregår overveiende med hendene. Hemmeligheten ligger, ifølge forfatteren, i langvaring, intens trening av følesansene - «slik blir hendene sensible instrumenter som kan oppdage små forandringer og forstyrrelser i kroppens vevsstrukturer». Osteopaten stoler på sensorapparatet $\mathrm{i}$ hendene sine. I Norden er det stort sett fysioterapeuter som tar utdanning i osteopati. 